\title{
An Integrated Model of CSR Perception and TAM on Intention to Adopt Mobile Banking
}

\author{
Van Anh NGUYEN ${ }^{1}$, Thi Phuong Thao NGUYEN²
}

Received: September 10, 2020 Revised: November 02, 2020 Accepted: November 16, 2020

\begin{abstract}
The purpose of this paper is to (1) evaluate a proposed conceptual model based on integrated Technology Acceptance Model (TAM) and Corporate Social Responsibility (CSR); (2) compare the differences between Vietnam and South Korea regarding the effects of consumer perception of CSR activities and technology acceptance on intention to adopt mobile banking. Structural Equation Modeling (SEM) was conducted to analyze the data collected from the field survey questionnaires administered to a convenience sample of Vietnamese and Korean banking customers. The results showed that there is a difference between South Korea and Vietnam with regard to intention to use mobile banking services. While the effects of social responsibility and environmental responsibility on trust, trust on perceived usefulness, perceived risk on intention to use, perceived usefulness on intention to use were significant in the context of Vietnam but those effects were not significant in South Korea. Therefore, this study has attempted to fill this gap by empirically examining some of the important factors influencing the adoption of $\mathrm{m}$-banking from the Vietnamese and Korean customers' perspectives. Finally, practical and theoretical implications for both banks and researchers in the m- banking context are also discussed in the concluding section.
\end{abstract}

Keywords: TAM, CSR, Behavioral Intention, Mobile Banking

JEL Classification Code: M14, M15, M31, M38

\section{Introduction}

Mobile financial services provide convenience and promptness to customers along with cost savings, banks are interested in expanding their market through mobile services. In the last several years, retail banks in Vietnam have introduced and diffused mobile banking systems throughout their operations to improve people's quality of life and to bring efficiency to banks. In fact, according to Zhou (2012) mobile banking (m-banking) allows people to perform bank transactions anytime and anywhere. With m-banking, users are able to access account balances, pay

${ }^{1}$ First Author and Corresponding Author. Lecturer, Faculty of Economics - Business Administration, Dalat University, Vietnam [Postal Address: 01-Phu Dong Thien Vuong Street, 8 Ward, Dalat City, Lam Dong Province, 670000, Vietnam] Email: anhnv@dlu.edu.vn

${ }^{2}$ Lecturer, Faculty of Economics - Business Administration, Dalat University, Vietnam. Email: thaontp@dlu.edu.vn

(C) Copyright: The Author(s)

This is an Open Access article distributed under the terms of the Creative Commons Attribution Non-Commercial License (https://creativecommons.org/licenses/by-nc/4.0/) which permits unrestricted non-commercial use, distribution, and reproduction in any medium, provided the original work is properly cited.
onrestricted non-commerial use bills, and transfer funds through mobile devices, instead of visiting banks or using internet banking based on computer (Gu, Lee, \& Suh, 2009). Mobile banking also benefits banks by promoting better efficiency and improved service quality. Data from 2019 shows that smart phone rate penetration in Vietnam was $72 \%$ whereas m-banking transactions consisted of about $20 \%$ of total bank transactions in 2019 so these numbers are relatively modest compared with many countries and it has not achieved its full potential. In other words, despite the fact that m-banking is beneficial to the customers, the adoption rate of m-banking in Vietnam is quite low and $\mathrm{m}$-banking adoption is still in the early stage in comparison to other services provided by the banks. Against this backdrop, understanding the consumer intention toward m-banking will be very crucial for the marketing strategy of banking institutions.

Furthermore, despite its rapid growth and its good economic performance, nowadays the Vietnamese business community has been facing important issues for its sustainable development, especially societal and environmental ones. Recent scandals of Vedan companies which committed serious pollution in Thi Vai River led to Vietnamese customers boycotting Vedan's product. 
In the same case, Coca-Cola Vietnam was also ignored by consumers due to transferring price incidentally during a decade to avoid paying governmental tax. In other words, Vietnamese customers are willing to boycott any corporations if they violate Corporate Social Responsibilities. In the same vein, after Formosa- Taiwan steel factory leaked toxic waste into the sea that caused massive fish deaths along a $200 \mathrm{~km}$ (124-mile) stretch of coastline in April 2016 and numerous cases of health safety problems especially toxic ingredients found out in consumer goods have raised a greater concern on corporate social responsibility (CSR) in Vietnam.

Hence, in this study the author adopted the TAM as the base model and adjusted the model to reflect the characteristics of mobile banking in Vietnam context by adding trust, three dimension of CSR (Economic responsibility, social responsibility, environmental responsibility), perceived risk and perceived cost factors to enhance understanding of $\mathrm{m}$-banking adoption intention of Vietnamese customers.

This study differs from some past studies as follows. First, most of the past studies have studied the relationship of trust and intention to use m-banking but this study is one of the first studies which investigated the relationship of the CSR with m-banking intention adoption through trust. Second, many studies proved CSR has a vital role in creating customer trust in Hospitality or Food industry and this study examined the role of CSR in banking industry, particularly in $\mathrm{m}$-banking, which has not yet been researched before. This study may find out valuable applications for bank managers to support their planning strategies and marketing campaigns that help banks develop sustainably. Finally, many scholars strongly support that the criteria for Mobile banking adoption and CSR activities in developing countries are different from that of developed countries, due to cultural, security, social, political, economic, and technological aspects. This research tried to investigate the differences on the adoption of mobile commerce between developed and developing countries.

The rest of this paper is structured as follows: the second section briefly presents an overview of the literature reiview and research model. In the third and fourth section, the methodology and data analysis are discussed, respectively. Discussion and concluding remarks are provided at the end.

\section{Theoretical Background and Hypohtheses}

\subsection{Theoretical Background}

M-banking has received considerable attention in academic research and thus several conceptualization of $\mathrm{m}$-banking currently exists. M-banking (m-banking) is defined as an application of m-commerce (Kim, Shin, \& Lee, 2009), an innovative method for accessing banking services that offers additional value for customers by providing "anytime, anywhere" access to banking service
(Lee \& Chung, 2009). Turban, King, Viehland, and Lee (2006) conceptualized m-banking as any form of banking transaction that is carried out through a mobile device, such as a mobile phone or a personal digital assistant.

CSR covers the economic, legal, ethical and discretionary expectations that society has of organizations at a given moment in time (Carroll, 1979). CSR is the commitment by a company to improve the welfare of its community by implementing certain discretionary practices and increasing the availability of its resources (Kotler \& Lee, 2005). Throughout the past several decades, numerous aspects of CSR have been the subject of investigation in academic and business literature. Although the nature and scope of the CSR remains uncertain, scholars have tried to summarize and categorize various CSR activities (Maignan \& Ferrell, 2001; Smith, 2003). One thing they all agree is that the purpose of business is to generate profits for shareholders, which is economic responsibility. In addition, following laws and legislations and keeping up with the business ethics seem to be a must-responsibility that society and the public automatically expect from any business. It is noted that although Carroll's (Carroll, 1998, 2000) four dimensions of CSR: economic, legal, ethical, and philanthropic responsibilities have been widely accepted among many scholars, existing marketing literature seems to generally agree on at least three dimensions of CSR: economic, philanthropic (also called social or discretionary), and environmental (Leigh, Murphy, \& Enis, 1988; Málovics, Csigéné, \& Kraus, 2008).

The literature showed that IT acceptance has been the subject of much research in the past two decades. One of the salient models is the Technology Acceptance Model (TAM), when it comes to investigating the factors that influence the adoption of information systems, which is proposed by Davis (1989) and is mainly developed from Fishbein and Ajzen's existing Theory of Reasoned Action (TRA). In particular, previous literature indicated that TAM consistently accounts for $40 \%$ of variance in usage intention and behaviors (Venkatesh \& Davis, 2000). TAM has been widely examined and validated and is an extensively accepted model in different sorts of technologies related to user and organization acceptance and adoption such as the World Wide Web (Lederer, Maupin, Sena, \& Zhuang, 2000; Van der Heijden, 2004; Tahar, Riyadh, Sofyani, \& Purnomo, 2020), Intranet (Horton, Buck, Waterson, \& Clegg, 2001), E-commerce (Olson \& Boyer, 2003; Pavlou, 2003; Han, Thao Nguyen, \& Nguyen, 2016), Internet Banking (AldásManzano, Lassala-Navarré, Ruiz-Mafé, \& Sanz-Blas, 2009), Mobile banking (Le, Trinh, \& Nguyen, 2020; Phuong, Luan, Dong, \& Khanh, 2020) that lead to their widespread acceptance.

Building customer trust, however, is a costly and timeconsuming exercise because trust relationships are formed 
in the course of long-term interactions between implicated parties (McKnight, Cummings, \& Chervany, 1998). Trust of this type is based on prolonged and cumulative experience that gives clients a sense of familiarity, calculation and values (Coleman, 1990). Cumulative experience significantly influences the level of customer trust in a vendor's competence, predictability and goodwill (Siau $\&$ Shen, 2003). In addition, customer trust in a firm may affect his/her loyalty to its services and the choice of service continuation or repurchase (Jarvenpaa, Tractinsky, \& Vitale, 2000). With the introduction of new innovative services, such as mobile banking, potential adopters have neither any prior experience to fall back on nor any experience or knowledge-based trust. Therefore, a person's initial trust is expected to be based on certain perceptions and possibly irrational forces such as cognitive cues (Kim, Shin, \& Lee, 2009). Researchers found that initial trust is significantly positively associated with mobile banking adoption intentions (Luo, Li, Zhang, \& Shim, 2010; Kim, Shin, \& Lee, 2009).

Furthermore, recently people are challenging sustainable development, especially environmental issues such as waste management and energy saving. Along with these environmental problems, there are numerous cases of health safety issues especially tainted milk distribution; toxic ingredients found in consumer goods have been raising a greater concern on corporate social responsibility in many countries. Therefore, it may be assumed that not only TAM but also CSR can predict the behavioral intention to adopt m-banking so in this study TAM model and CSR initiatives are combined firstly in our research model. The model consists of eight constructs that are posited to have an effect on behavioral intention to use $\mathrm{m}$-banking services which was developed in Figure 1.

\subsection{Hypotheses Development}

\subsubsection{CSR Initiatives}

Previous studies have used the concept of CSR in marketing and consumer behavior literature. Several studies have attempted to investigate the effects of CSR on factors such as customer loyalty, trust, word of mouth, intentions, attitudes, satisfaction, and brand identification (Luo \& Bhattacharya, 2006; Handelman \& Arnold, 1999; Sen \& Bhattacharya, 2001). From an economic perspective, the fundamental motivation for CSR is to maximize firm profitability for shareholders (Zenisek, 1979). However, some scholars indicated that corporations bear a responsibility to contribute to the betterment of society as a whole (Brown \& Dacin, 1997; Davis, 1975; Drumwright, 1996; Handelman \& Arnold, 1999), as well as to integrate environmental concerns in business operations (Dahlsrud, 2008; Homburg, Koschate, \& Hoyer, 2005).

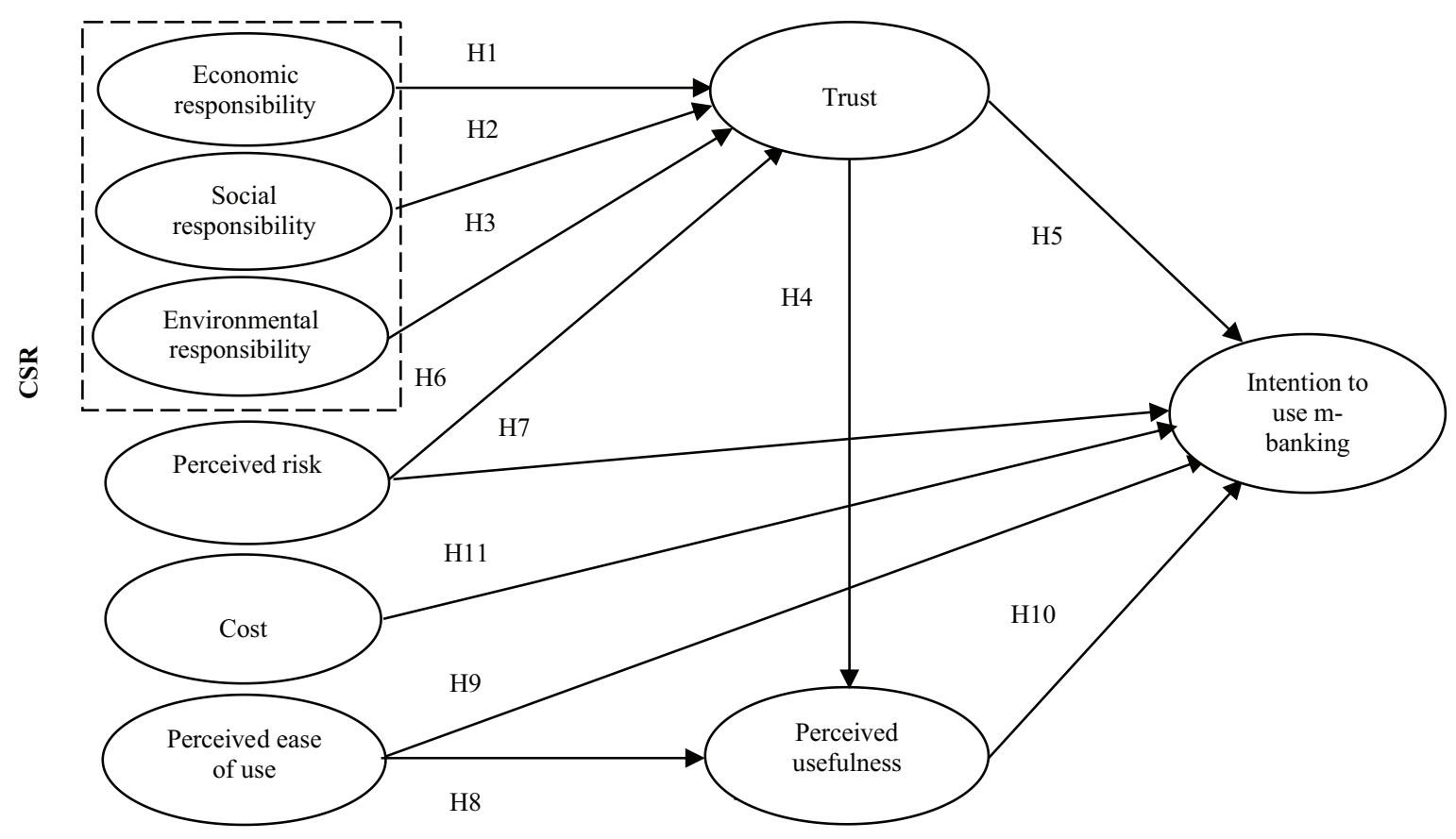

Figure 1: Research model 
A firm's CSR activities may engender its image of honesty, integrity, credibility and high responsiveness towards customer concerns (Sirdeshmukh, Singh, \& Sabol, 2002). Maignan and Ferrell (2000) argue that a firm's CSR activities can be a good source of customer trust and reduction of skepticism. For example, Swaen and Chumpitaz (2008) studied cosmetics and sportswear customers and reported that CSR perceptions make a positive impact on customer trust. These scholars argue that CSR perceptions and trust are significant variables in the cultivation of long-term affiliations between customers and firms. Moreover, Del Mar Garcia de los Salmones, Perez, and Rodriguez del Bosque (2009) identify a direct relationship between a firm's ethical responsibility and customer trust in retail service markets. Similarly, Choi and La (2013) state that a firm's ethical-legal responsibility positively affects customer trust in service contexts.

In addition, in recent decades customers have experienced changes in customer's behavior; "green consumption" is the primary trend of consumption around the world. Not only do consumers desire using high quality products but also they crave for safer and friendlier products which are produced by highly reputable and responsible organization who are concerned with individual environment (Chan, 1996) and are aware towards consumer environment (Kim \& Choi, 2005; Verhoef, 2005) affecting positively to purchasing intention of consumers. Therefore, based on the theoretical and empirical arguments stated above, the following hypotheses are proposed:

H1. Economic responsibility has a positive impact on trust

H2. Social responsibility has a positive impact on trust

H3. Environmental responsibility has a positive impact on trust

\subsubsection{Trust}

Mobile banking is an exchange situation without the physical presence of branch and personal interactions. Therefore, trust is a crucial element for decision making (Zhou, 2011; Grabner-Krauter \& Kaluscha, 2003). While consumers initially trust their e-vendors and have an idea that adopting online service is beneficial to job performance or life style, they will eventually believe that online services are useful (Gefen, Karahanna, \& Straub, 2003). In particular, Gefen, Karahanna, and Straub (2003) investigated the role of trust in an on-line shopping setting explicitly indicated that trust is an antecedent of perceived usefulness. Trust also has a direct influence on a consumer's behavioral intention to use the service (Wu \& Chen 2005). Trust is one of the determinants of perceived usefulness especially in an online environment (Vlachos, Tsamakos, Vrechopoulos, \& Avramidis, 2009). Pavlou (2003) also found that trust has a positive effect on perceived usefulness in an e-commerce setting.
H4: Trust has a positive impact on the perceived usefulness of $m$ - banking services.

H5: Trust has a positive impact on the behavioral intention to use m-banking services

\subsubsection{Perceived Risk}

Due to the high degree of uncertainty and perceived risk in e-commerce operations, trust becomes an important factor for people to obtain confidence on an exchange partner. Customers need to trust in m-banking to use it. Viruses and Trojan horses may exist in mobile terminals too; so, these problems increase users' concern about payment security, and decrease their trust in m-banking, which, in turn, can affect their usage intention and behavior (Zhou, 2012).

Indeed, risk perception is one of the main barriers to m-banking adoption in Brazil (Cruz, Neto, Muñoz-Gallego, \& Laukkanen, 2010), the most important in China (Laforet \& Li, 2005; Faqih \& Jaradat, 2015) and has a significant relationship with users' attitudes and intention to use m-banking in Iran (Mohammadi, 2015). This construct also has significant relationship with internet banking adoption (Yiu, Grant, \& Edgar, 2007) and with customer's lack of interest in online commercial transactions (Liao, Liu, \& Chen, 2011). The perception of risk is a significant factor affecting trust (Al-Gahtani, 2011) and affecting mobile banking adoption (Al-Jabri \& Sohail, 2012; Ha, Canedoli, Baur, \& Bick, 2012). As risk perception can generate a negative effect on trust, the researcher included this variable in the model.

A closer look at the relevant studies leads the author to observe that perceived risk is one of the most important obstacles hindering the customers' willingness to adopt m-banking (Akturan \& Tezcan, 2012; Hanafizadeh, Behboudi, Abedini, \& Jalilvand, 2014). Accordingly, this study assumes the following hypothesis:

H6: Perceived risk has a negative impact on trust

H7: Perceived risk has a negative impact on behavioral intention to use of m-banking services

\subsubsection{Perceived Ease of Use}

Perceived ease of use is conceptualized as an individual's assessment of the mental effort involved in using the new technology (Davis, 1989). Various other studies (Davis, 1986; 1989) also pointed that perceived ease of use can influence perceived usefulness because other things being equal the easier the technology is to use the more useful it can be. In the context of internet banking, research shows that perceived ease of use has a positive and significant effect on perceived usefulness (Wang, Lo, 
\& Hui, 2003). According to Akturan and Tezcan (2012); Wang, Lin, and Luarn (2006) perceived ease of use has a positive relationship with intention to adopt m-banking. The researchers concluded that if customers perceive mobile banking to be easy to learn and use, adoption of the service follows. Thus, the following hypotheses are developed:

H8: Perceived ease of use has a positive impact on perceived usefulness to use m-banking services.

H9: Perceived ease of use has a positive impact on behavioral intention to use m-banking services.

\subsubsection{Perceived Usefulness}

Davis (1989) defined perceived usefulness as the extent to which individuals believe that using the new technology will enhance their task performance. In the context of user acceptance of m-banking services, perceived usefulness could be because of transactions like online request for cheque/demand draft, sending monthly e-statements, online payments, etc. that improves performance, saves time and increase effectiveness of service or some or several addon benefits such as bill payments, mobile recharge, etc. These benefits are also expected to become even better in the coming time through technological advancement or breakthrough.

Extensive research has provided ample evidence of the significant positive effect of perceived usefulness on the development of the initial willingness to use mobile banking (Aboelmaged \& Gebba, 2013; Wang, Lin, \& Luarn, 2006; Luarn \& Lin, 2005). Luarn and Lin (2005) stated that the ultimate reason that people employ mobile service systems is that they find the systems useful for their banking transactions. Therefore, the following hypothesis is proposed:

H10: Perceived usefulness has a positive impact on individual behavioral intention to use m-banking services.

\subsubsection{Perceived Cost}

Perceived financial cost is defined as the extent to which a person believes that he or she has the financial resources needed to use a system because purchasing, using, and maintaining a system costs money (Wang, Lin, \& Luarn, 2006). Perceived financial cost has been found to have a significant negative influence on the behavioral intention to use mobile banking (Wessels \& Drennan, 2010; Wang, Lin, \& Luarn, 2006; Luarn \& Lin, 2005).

H11: Perceived cost has a negative impact on the behavioral intention to use m-banking services

\section{Methodology}

A typical seven-point Likert scale was used to measure the constructs presented in the proposed model (scores were ranged from $1=$ "strongly agree" to $7=$ "strongly disagree" with "neutral" score =4). The conceptualization and development of the questionnaire was based on the existing literature. Perceived risk was adapted from Featherman and Pavlou (2003). Intention to use m-banking (three items) and perceived ease of use (three items) and perceived usefulness (four items) were adopted from Cheng, Lama, and Yeung (2006); Nasri and Charfeddine (2012). Three dimensions of CSR including 9 items were adapted from Zhu, Sarkis, and Lai (2013); Park and Lee (2009). Perceived cost including three items was adapted from Kim, Chan, and Gupta (2007). In this study, the measures of trust including six items were based on studies in marketing area which examined the relationship between trust and various constructs and trust is the overall trust about the bank, so trust measurement was adapted from Wei, Marthandan, Chong, Ooi, and Arumugam (2009); Suh and Han (2002).

Data was collected by using a paper-based survey questionnaire in Vietnam and South Korea through support from professors and students of the universities in Vietnam and South Korea. After gathering the answered questionnaires, they were checked thoroughly to assess the reliability and validity as to whether to include them in study or not. There were 612 questionnaires from Vietnam and 267 from Korea which were used for the final analysis.

Since SEM procedures require normal distribution of data (Hatcher, 1994), the skewness and kurtosis tests were performed using SPSS 20 for Windows to scrutinize univariate normality for each of the variables in the model. Skewness refers to asymmetry of the distribution while kurtosis measures the peakedness or flatness of the distribution (Hopkins \& Weeks, 1990). DeCarlo (1997) suggested that a sample's skewness and kurtosis values should be within the range of -3 and 3 . By applying the above criteria to the skewness and kurtosis coefficients for each of the observed variables were within the +3 to -3 range for skewness and Kurtosis. Hence, these results provide clear evidence that scaled data for the study are normally distributed with no outlying observations.

\section{Data analysis}

\subsection{Demographic results}

The respondent demographics are summarized in table 1. Both in Vietnam and South Korea respondents are male which is slightly more than female. In South Korea almost $97 \%$ of respondents were aged from 20 to 30 years old whereas in Vietnam the respondents age was between 20-30 years and 31-40 year old respondents accounted for $83 \%$. 
The majority of respondent's education level was undergraduate in both samples. In addition, like in the case of Vietnam, the percentage of the sample who were living in big cities in South Korea was slightly higher than in the smaller cities. Finally, most respondents had used m-banking for more than two years in both countries.

As a whole, this sample consisted of generally young, well-educated consumers with a high level of income. These characteristics are representative of $\mathrm{m}$-banking users with a young age as well as higher education and income levels compared to the general population.

\subsection{Reliability and Validity Analysis}

Reliability test was done to test the degree to which the set of latent construct indicators were consistent in their measurements. The reliability of the variables was assessed by the Cronbach's Alpha and Item-total Correlation. The acceptable threshold for Cronbach's Alpha is 0.70, while constructs which are highly inter-correlated indicate that they are all measuring the same latent constructs. The resulting alpha values range from 0.816 to 0.930 which are above the acceptable threshold of 0.7 . Also, the item-total correlation test results are satisfactory.

A confirmatory factor analysis was conducted to test the measurement model. This assesses what the construct or scale is, in fact, measuring. To construct validity, two checks have to be performed: the convergent validity and discriminant validity. All the model-fit indices exceeded their respective common acceptance levels suggested by previous research, thus demonstrating that the measurement model exhibited a good fit with the data collected $\chi^{2}{ }_{(612)}=874.934, \mathrm{CMIN} /$ $\mathrm{df}=2.566, \mathrm{p}=.000 ; \mathrm{GFI}=0.911 ; \mathrm{TLI}=0.953 ; \mathrm{CFI}=0.960$; RMSEA $=0.051$.

Values for composite reliability are recommended to exceed 0.70 (Chin, Marcolin, \& Newsted, 2003) and AVE values should be greater than the generally-recognized cutoff value of 0.50 (Fornell \& Larcker, 1981). Table 2 shows that all composite reliability and AVE values meet the recommended threshold values. Therefore, it is an evidence for the convergent validity. In addition, the square root of AVE for each construct is greater than the correlations between the constructs and all other constructs, indicating that these constructs have discriminant validity.

Table 1: Descriptive of respondent's characteristic

\begin{tabular}{|c|c|c|c|c|c|}
\hline \multirow{2}{*}{\multicolumn{2}{|c|}{ Demographics }} & \multicolumn{2}{|c|}{ Vietnam } & \multicolumn{2}{|c|}{ South Korea } \\
\hline & & \multirow{2}{*}{$\begin{array}{c}\begin{array}{c}\text { Respondents } \\
(\mathbf{N}=612)\end{array} \\
363\end{array}$} & \multirow{2}{*}{$\begin{array}{c}\begin{array}{c}\text { Percentage } \\
(\%)\end{array} \\
59.3\end{array}$} & \multirow{2}{*}{$\begin{array}{c}\begin{array}{c}\text { Respondents } \\
(\mathbf{N}=\mathbf{2 6 7})\end{array} \\
160\end{array}$} & \multirow{2}{*}{$\begin{array}{c}\begin{array}{c}\text { Percentage } \\
\text { (\%) }\end{array} \\
59.9\end{array}$} \\
\hline & Male & & & & \\
\hline Genaer & Female & 249 & 40.7 & 107 & 40.1 \\
\hline \multirow{5}{*}{ Age } & $<20$ & 57 & 9.3 & 8 & 3.0 \\
\hline & $20-30$ & 296 & 48.4 & 259 & 97.0 \\
\hline & $31-40$ & 212 & 34.6 & - & - \\
\hline & $41-50$ & 29 & 4.7 & - & - \\
\hline & $>50$ & 18 & 2.9 & - & - \\
\hline \multirow{4}{*}{ Education } & High school & 15 & 2.5 & - & - \\
\hline & College & 45 & 7.4 & 72 & 27.0 \\
\hline & Undergraduate & 367 & 60.0 & 166 & 62.2 \\
\hline & Graduate & 185 & 30.2 & 29 & 10.9 \\
\hline \multirow{2}{*}{ Living area } & Big city & 317 & 51.8 & 157 & 58.8 \\
\hline & Small city & 295 & 48.2 & 110 & 41.2 \\
\hline \multirow{3}{*}{ Usage duration } & $<1$ year & 115 & 18.8 & 29 & 10.9 \\
\hline & $1-2$ years & 160 & 26.1 & 51 & 19.1 \\
\hline & $>2$ years & 337 & 55.1 & 187 & 70 \\
\hline
\end{tabular}


Table 2: Composite reliability, AVE and correlation of constructs' values

\begin{tabular}{|l|c|c|c|c|c|c|c|c|c|c|c|}
\hline VIETNAM & CR & AVE & $\mathbf{1}$ & $\mathbf{2}$ & $\mathbf{3}$ & $\mathbf{4}$ & $\mathbf{5}$ & $\mathbf{6}$ & $\mathbf{7}$ & $\mathbf{8}$ & $\mathbf{9}$ \\
\hline 1.RISK & 0.903 & 0.756 & 0.869 & & & & & & & & \\
\hline 2.TRUST & 0.901 & 0.695 & -0.802 & 0.834 & & & & & & & \\
\hline 3.SOCIAL & 0.838 & 0.635 & -0.444 & 0.412 & 0.797 & & & & & & \\
\hline 4.ENVIRONMENT & 0.900 & 0.751 & -0.418 & 0.385 & 0.713 & 0.866 & & & & & \\
\hline 5.USEFULNESS & 0.915 & 0.729 & -0.404 & 0.540 & 0.277 & 0.253 & 0.854 & & & & \\
\hline 6.COST & 0.931 & 0.819 & -0.387 & 0.502 & 0.356 & 0.287 & 0.524 & 0.905 & & & \\
\hline 7.ECONOMIC & 0.817 & 0.598 & -0.410 & 0.487 & 0.658 & 0.474 & 0.490 & 0.439 & 0.773 & & \\
\hline 8.EASY OF USE & 0.852 & 0.659 & -0.492 & 0.641 & 0.211 & 0.236 & 0.701 & 0.493 & 0.387 & 0.812 & \\
\hline 9.INTENTION & 0.887 & 0.723 & -0.668 & 0.741 & 0.368 & 0.374 & 0.647 & 0.452 & 0.538 & 0.677 & 0.850 \\
\hline
\end{tabular}

Note: Diagonal elements are the square root of AVE. Off-diagonal elements are the correlations among constructs.

Table 3: Unstandardized structural paths

\begin{tabular}{|l|c|c|c|c|c|}
\hline \multirow{2}{*}{ Hypothesis } & \multicolumn{5}{|c|}{ Vietnam } \\
\cline { 2 - 6 } & R.E & S.E & t value & P & Result \\
\hline H1:Economic responsibility $\rightarrow$ Trust & .371 & .057 & 6.570 & .000 & $S^{* *}$ \\
\hline H2: Social responsibility $\rightarrow$ Trust & .321 & .092 & 3.477 & .000 & $S^{* *}$ \\
\hline H3: Environmental responsibility $\rightarrow$ Trust & .164 & .062 & 2.639 & .008 & $S^{* *}$ \\
\hline H4: Trust $\rightarrow$ Perceived Usefulness. & .135 & .034 & 3.925 & .000 & $S^{* *}$ \\
\hline H5: Trust $\rightarrow$ Intention To Use & .339 & .062 & 5.461 & .000 & $S^{* *}$ \\
\hline H6: Perceived risk $\rightarrow$ Trust & -.688 & .039 & -17.616 & .000 & $S^{* *}$ \\
\hline H7: Perceived risk $\rightarrow$ Intention To Use & -.176 & .056 & -3.126 & .002 & $S^{* *}$ \\
\hline H8: Perceived ease of use $\rightarrow$ Perceived usefulness & .585 & .045 & 13.047 & .000 & $S^{* *}$ \\
\hline H9: Perceived ease of use $\rightarrow$ Intention To Use & .249 & .059 & 4.238 & .000 & $S^{* *}$ \\
\hline H10: Perceived usefulness $\rightarrow$ Intention To Use & .280 & .055 & 5.058 & .000 & $S^{* *}$ \\
\hline H11:Perceived cost $\rightarrow$ Intention To Use & -.019 & .028 & -.666 & .505 & $\mathrm{NS}$ \\
\hline
\end{tabular}

Note: **: significant at $\mathrm{P}<0.01$; S: Support; NS: Not support; P: P-value.

\subsection{Structural Results: Hypothesis Testing}

SEM was used to test the hypotheses in South Korea and Vietnam. The SEM results indicated that the model had an acceptable fit in Vietnam better than in South Korea. In particular, the indices of model with data collected in Vietnam are $\chi 2_{(612)}=999.183, \mathrm{CMIN} / \mathrm{df}=2.855, \mathrm{p}=.000 ; \mathrm{GFI}=0.898$; $\mathrm{TLI}=0.944 ; \mathrm{CFI}=0.952 ; \mathrm{RMSEA}=0.055$ while for South Korea are $\chi 2(267)=1055.350, \mathrm{CMIN} / \mathrm{df}=2.833, \mathrm{p}=.000$; $\mathrm{GFI}=0.790 ; \mathrm{TLI}=0.831 ; \mathrm{CFI}=0.848 ; \mathrm{RMSEA}=0.084$.

Table 3 presents the unstandardized structural paths; and Figure 2 presents the significant structural relationship among the research variables and the standardized path coefficients with their respective significance levels in Vietnam. Only 1 of 11 hypotheses proposed is found insignificant (H11). In addition, the figure 3 shows the model explained substantial variance in both perceived usefulness $\left(\mathrm{R}^{2}=52 \%\right)$, Trust $\left(\mathrm{R}^{2}=73.5 \%\right)$ and intention to use $\left(\mathrm{R}^{2}=67.4 \%\right)$.
In South Korea, As we expected, differences were observed between the South Korea and Vietnam in regard to intention to use m-banking services. As shown in table 4, five out of eleven links in the research model were different across the two cultures. While the effects of social responsibility and environmental responsibility on trust, trust on perceived usefulness, perceived risk on intention to use, perceived usefulness on intentions to use were significant for the Vietnam sample, those effects were not significant in the South Korea sample. These findings were attributed to information technological infrastructure, mobile commerce development, m-banking penetration level and environmental matter. Sims and Gegez (2004) found that the attitudes toward business ethics were different along some dimensions, also the difference in the impact of CSR to trust may be attributed to Vietnam regulation about the environment protection is not be considered carefully in developing national economy so Vietnam are facing a lot of environmental crisis which is quite different from South Korea. 


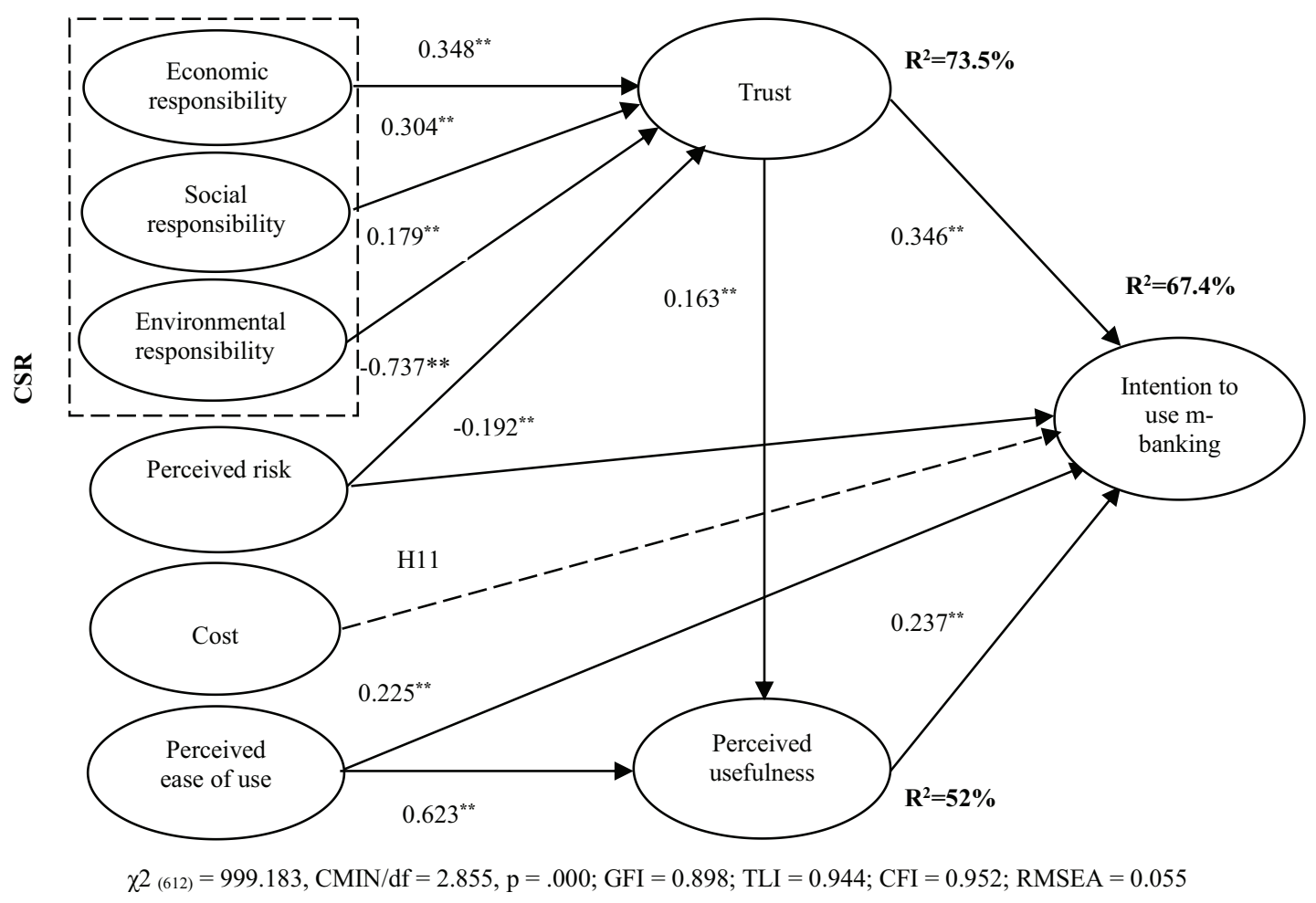

Figure 2: Results of testing Hypotheses of Viet Nam

They also recognized that technology infrastructure differences between South Korea and Vietnam were the driving forces behind their disparate views. To further understand our findings, I subsequently examined the inconsistencies in light of information technological infrastructure, mobile commerce development, m-banking penetration level and environmental protection regulation differences in the following sections. It is important to note that these factors are not directly measured in this study and I am simply providing the subsequent analyses as potential explanations to differences observed between the South Korea and Vietnam subjects.

In South Korea, perceived usefulness has no significant relationship with consumer intention to adopt m-banking. This variable is derived from the TAM model. As stated by Jeyaraj, Rottman, \& Lacity (2006), this variable is a good predictor of IT usage in past studies. However, although m-banking is a relatively new technology, South Korean consumers are no strangers to mobile phones. Therefore, South Korean consumers have a good understanding of what $\mathrm{m}$-commerce and m-banking can offer, and thus will not be attracted to use $\mathrm{m}$-banking based on the perceived usefulness or being given free trials. This result contradicts with the findings from Koenig-Lewis, Palmer, and Moll (2010) and Hanafizadeh, Behboudi, Abedini, and Jalilvand (2014) which call for $\mathrm{m}$-banking providers to focus on promoting the advantages offered by m-banking.
A further difference between the two countries is the effect of environmental responsibility on the customer's trust. The status and environment regulation and environment crisis in the two countries can be used to explain the notable differences. In Vietnam, there are many environmental problems due to the fast development objectives such as waste management, energy saving. Recent scandals of factories committed serious pollution that polluted soil and water that caused a bad impact on safe drinking water for the Vietnamese population. In addition numerous cases of health safety problems especially tainted milk distribution; toxic ingredients were found in consumer goods which were raising a greater concern on corporate social responsibility in Vietnam. That is why in this research, environmental responsibility is one of the most important factors that affects customer behavior through the trust in Vietnam sample but not in South Korean one.

In addition, with developed information and technology infrastructure as well as security mechanism and solution of South Korean banks, especially with the latest iris technology used by South Korean banks prove that security of banks in South Korea is much more better than the Vietnamese banks so South Korean customers perceived less risk regard m-banking than the Vietnamese customers. That's why perceived risk has no impact on intention to use in South Korea but it did in Vietnam. 


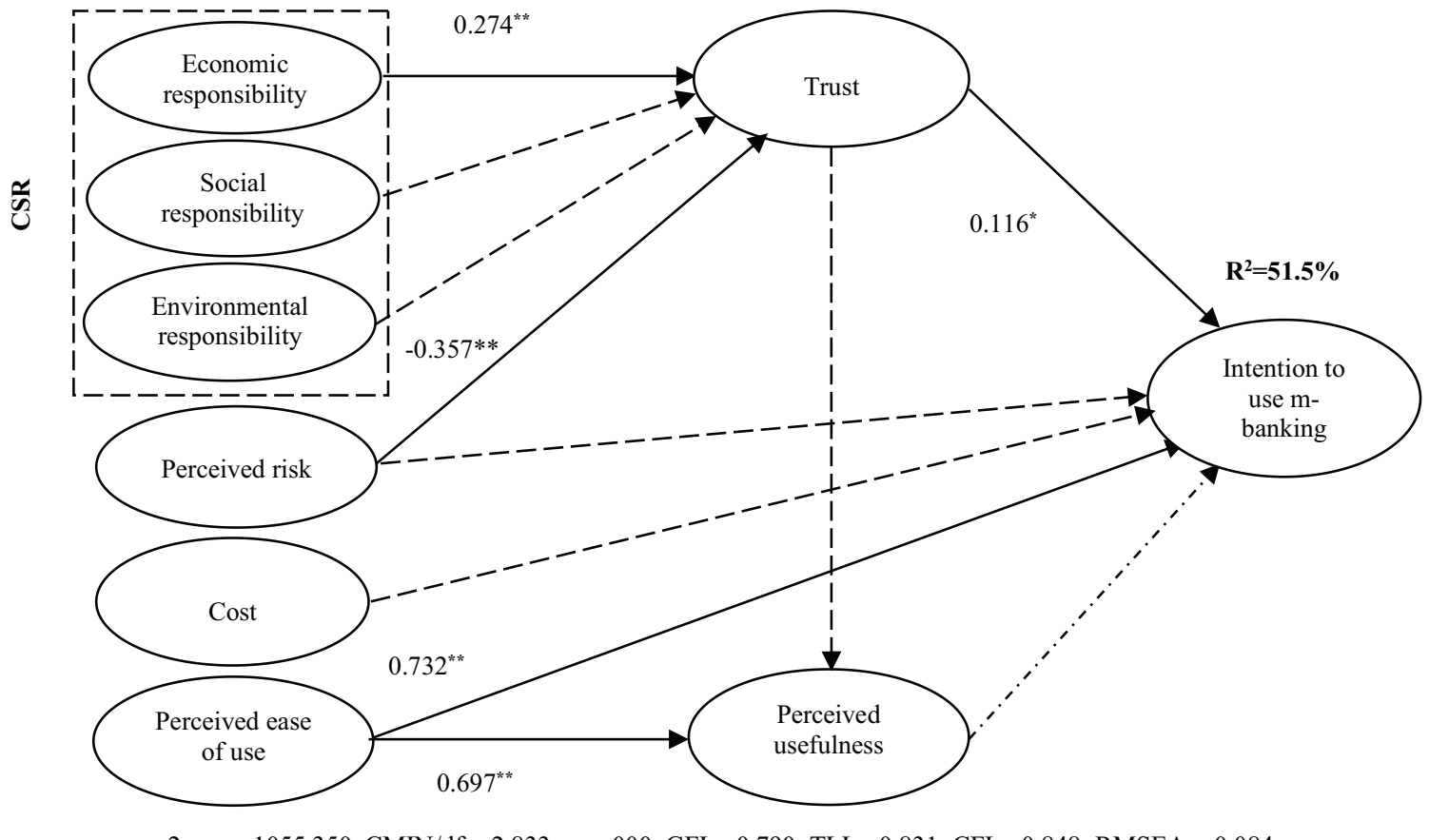

$\chi 2_{(267)}=1055.350, \mathrm{CMIN} / \mathrm{df}=2.833, \mathrm{p}=.000 ; \mathrm{GFI}=0.790 ; \mathrm{TLI}=0.831 ; \mathrm{CFI}=0.848 ; \mathrm{RMSEA}=0.084$

Figure 3: Results of testing Hypotheses of South Korea

Table 4: Comparison results Vietnam versus South Korea

\begin{tabular}{|c|c|c|}
\hline \multirow{2}{*}{ Hypotheses } & \multicolumn{2}{|c|}{ Results } \\
\hline & Vietnam & South Korea \\
\hline $\mathrm{H} 1:$ Economic responsibility $\rightarrow$ Trust & Accept & Accept \\
\hline H2: Social responsibility $\rightarrow$ Trust & Accept & Reject \\
\hline H3: Environmental responsibility $\rightarrow$ Trust & Accept & Reject \\
\hline H4: Trust $\rightarrow$ Perceived Usefulness. & Accept & Reject \\
\hline H5: Trust $\rightarrow$ Intention To Use & Accept & Accept \\
\hline H6: Perceived risk $\rightarrow$ Trust & Accept & Accept \\
\hline H7: Perceived risk $\rightarrow$ Intention To Use & Accept & Reject \\
\hline H8: Perceived ease of use $\rightarrow$ Perceived usefulness & Accept & Accept \\
\hline H9: Perceived ease of use $\rightarrow$ Intention To Use & Accept & Accept \\
\hline H10: Perceived usefulness $\rightarrow$ Intention To Use & Accept & Reject \\
\hline H11:Perceived cost $\rightarrow$ Intention To Use & Reject & Reject \\
\hline
\end{tabular}


Interestingly, this research found that trust and perceived ease of use play a significant role in m-banking adoption intention by both South Korean and Vietnamese consumers. The result shows both South Korean and Vietnamese users generally need trust on the transactions that lack physical contact. In case of South Korean consumers, this results is quite consistent with suggestions by Hofstede (1994) that South Korean consumers are less likely to take risks since according to Hofstede (1994) the uncertainty avoidance score is 85 in comparison with the uncertainty avoidance score of Vietnam is 30. In case of Vietnam, it is implied that even though Vietnamese are likely to take risks more than the South Korean users but in Vietnam risks still exists a lot in m-banking system due to the security system of Vietnamese banks is quite opposite to that of the South Korean banks, besides banking is related to money therefore, the customers are very sensitive to security, and without trust anybody just can not adopt to m-banking services. That is why according to the theory of Hofstede, the uncertainty avoidance score of South Korean and Vietnamese users is quite different but the results showed that trust plays the vital role in m-banking intention to use not only in Vietnam but also in South Korea.

\section{Disscussions, Implications, and Conclusion}

\subsection{Discussions}

The statistical results highly proved Trust as a key factor predicting BI with a regression weight of 0.346. In other words, Vietnamese customers seem to be more motivated to adopt m-banking if they trust they trust banks. This could be attributed to in m-banking there are growing many concerns about risk in online banking services because it is operated in an open environment, their applications and outcomes are vulnerable to security and threats such as theft, fraud breaches of personal privacy and attacks by hackers. Theoretically, these results are parallel with prior studies of m-banking that have tested and approved trust as a crucial factor in determining the customers' intention on on m-banking adoption (Hanafizadeh, Behboudi, Abedini, \& Jalilvand, 2014; Lee \& Chung, 2009).

The empirical results have also shown that there is a relationship between perceived usefulness and adoption intention of m-banking with a regression weight of 0.237 . Hence, it can be implied that Vietnamese customers will use $\mathrm{m}$-banking if they perceive it as more effective, productive and a useful technology. These findings consistent with previous study of m-banking that tested the relationship between perceived usefulness and customer's intention to use m-banking (Akturan \& Tezcan, 2012; Hanafizadeh, Behboudi, Abedini, \& Jalilvand, 2014; Luarn \& Lin, 2005).

In addition, the empirical results have also supported the significant relationship between perceived ease of use and behavioral intention with a weight of 0.225 . This, in turn, means that respondents were more likely to have a higher intention to adopt m-banking if they perceived that the use of such technology was not difficult and required less effort. Such results of perceived ease of use extracted in the current study are in line with existing literature in the IS area (Venkatesh, Morris, Davis, \& Davis, 2003) and in m-banking (Gu, Lee, \& Suh, 2009; Hanafizadeh, Behboudi, Abedini, \& Jalilvand, 2014; Luarn \& Lin, 2005). Perceived ease of use was also found to be a key predictor of perceived usefulness with a weight of 0.623 . If the customers perceive that using m-banking needs less effort and is not difficult, they will perceive to use such a system more advantageously and be more useful in their daily life (Davis, Bagozzi, \& Warshaw, 1989). Furthermore, perceived usefulness showed higher effect on intention to use m-banking in comparison with ease of use and this underlines seriousness of perceived usefulness in Vietnamese' m-banking usage. It sounds better to say that for the managers of the bank to improve users' attitudes, they need to pay more attention to improving system's usefulness while investing in its ease of use.

Surprisingly, this study discovered that perceived costs is not associated with the adoption level of mobile banking, whereas the findings of previous studies about m-banking adoption intention in Australia, Iran and Taiwan have revealed that perceived cost was found to affect consumer acceptance of m-banking (Wessels \& Drennan, 2010; Hanafizadeh, Behboudi, Abedini, \& Jalilvand, 2014; Luarn $\&$ Lin, 2005). This contradiction could be explained by the fact that Vietnamese customers just have to pay 3.300 VND fee when they transfer money instead of 22.000 VND if they make that transaction at the bank.

Finally, this study empirically proved that perceived risk was a significant negative factor determining the behavioral intention to adopt m-banking with a regression weight of -0.192 . Accordingly, it could be concluded that Vietnamese customers are less likely to be encouraged to adopt m-banking with a higher degree of expectation of suffering a loss as a result of using such a system. This relationship could return to the particular and sensitive nature of the banking industry in general as well as online banking technology which is universally characterized by a high uncertainty, intangibility, heterogeneity, and vagueness along with the absence of human interaction (Akturan \& Tezcan, 2012). This could be attributed to the increase in the number of electronic financial crimes in Vietnam recently. The result is consistent with previous findings found that there is a strong relationship between the perceived risk on the German customers' acceptance of m-banking (KoenigLewis, Palmer, \& Moll, 2010).

In South Korea, although technology acceptance model (TAM) was not found fully and significantly supported, the effect perceived usefulness should not be overlooked in the 
adoption intention to use m-banking services. In addition, the relationship between perceived cost and intention to use m-banking was found insignificant, which is consistent with the finding in Vietnam. Additionally, this study established trust and perceived ease of use as two important antecedents of behavioral intention to use m-banking which were able to account for a substantial amount of variance $(51.5 \%)$ in behavioral intention. Empirical results indicated that perceived risk was not an antecedent of adoption intention of m-banking. Nevertheless, a relationship between perceived risk and trust was evident in this study which showed a significant path through the model from perceived risk to behavioral intention to use with trust as the mediating variable. Hence, perception of risk should also be important to the intention to use m-banking services in South Korea.

\subsection{Implications}

The results give some important implications for developers, manager to formulate strategies. Firstly, in Vietnam setting, perceived ease of browsing, identifying information and performing transactions should facilitate favorable and persuasive information about new products and must demonstrate usefulness for consumers. Also, banks should attempt to enhance consumers' perceptions of the beneficial features and nature of m-banking. Marketing activities should focus on the tangible and immediate benefits of using m-banking services including quicker financial transaction speed, broader varieties of financial services, and enhanced financial transparency. Besides, expanding the range of financial services provided by the m-banking and maintaining the permanency of their performance efficiently and effectively, 24/7 will support the role of perceived usefulness (Zhou \& Wang, 2010). Moreover, a simple and friendly design of m-banking services will not only enhance the perceived ease of use in using such a channel but will also contribute to the role of perceived usefulness (Jaruwachirathanakul \& Fink, 2005). An effective, personal, and practical training program that will educate customers on how they can efficiently use m-banking could be more helpful to override any complexity and confusion related to the use of this system. Concurrently, security risks related to the new innovation should be strongly minimized. Thus, banks should search for risk-reducing strategies that might contribute in arousing high confidence in prospecting customers. Other strategies that could be more useful in mitigating PR include a money-back guarantee policy in the case of mistakes and false transactional data entry, providing them with circulatory passwords and ability to change passwords to enhance security in personal financial transactions and providing the system with tracing codes in consumers' transactions for them to be able to track problems if they occurred seem to help this perception. Trust was also identified as a factor that positively affected intention to use $\mathrm{m}$-banking. The current findings suggest that CSR initiatives can help to build customer trust. Therefore, managers should recognize the influence of CSR on gaining trust of customers to make them adopt m-banking services.

Secondly, in South Korea, bank managers may also need to be aware of importance of CSR not only as a key variable in building customer trust in mobile banking but also as a factor that leads to various outcomes, including enhanced cumulative satisfaction, loyalty, and positive word-of-mouth. Specially, South Korean banks should focus on economic dimension by creating more wealth for society, increasing wages for employees, providing good products and good service at a reasonable price instead of paying attention to environmental or social issues. Besides, riskreducing strategy also should not be overlooked since South Korean customers are also not likely to adopt m-banking if they perceive risk which in turn decreases their trust in m-banking services.

\subsection{Conclusion}

The results of this study indicated that behavioral intention to use m-banking is significantly determined, supported and validated by the concepts of CSR through trust. Among the subjective factors of CSR, economic responsibility is found as a more significant determinant of customer trust than environmental and social responsibility. These findings could be explained by the nature of Bank service market. The bank industry is one of the most competitive and economic activities of banks including new job creation, value contributions and investments to the society are the main responsibility of Vietnam Banks. Besides, the results indicated that environmental responsibility affects behavioral intention stronger than the social responsibility. This can be attributed to the fact that during the past few years, Vietnamese consumers have been facing serious food safety, and health problems due to the environmental crisis. Therefore, banks should incorporate CSR initiatives in their integrated marketing communication strategy in particular branding strategy so as to attract more customers.

Beside that, this research has theoretical and practical contributions. The study makes a strong contribution to the current $\mathrm{m}$-banking literature by extending TAM to include perceived risk, perceived cost, trust and three dimensions CSR that previous TAM studies in the context of m-banking did not include. The results of the present study suggest that perceptions of CSR have a positive impact on customer trust in mobile banking services. Therefore, the findings of the present research are particularly noteworthy because this is the first research that proves the link between perceived CSR activities and customer trust in the context of mobile banking services. In addition, the practical value of this research is that 
it expands our understanding of $m$-banking by identifying and synthesizing the most important factors influencing customer adoption of m-banking services in Vietnam and South Korea. The practical implications of these findings are that adding the understanding of $\mathrm{m}$-banking from a consumer's behavior perspective and, therefore, acts as a valuable base for banks. Specifically, the findings highlight that particular factors (perceived ease of use, perceived usefulness, perceived risk, trust as well as CSR initiatives) will determine customer behavioral intention to adopt m-banking services. Finally there are some differences between about the role of each factor in our research model which depends on context such as the developing and developed country.

\subsection{Limitation and Future Research}

The current study is restricted by some limitations and can be reported as follows. First there are other factors that have been ignored and therefore should be measured by future research such as self-efficacy, resistance change and technology readiness. Secondly, this study concentrated on the customers' intention adoption; yet, customer satisfaction, word-of-mouth, and customer loyalty as a consequence of using m-banking will be valuable directions to be examined in future researches. Thirdly, as the current research is applying the survey-based method, it could be argued that this method is prone to the inherent limitation of measurement errors. However, the measurement errors were reduced, as indicated by the study's good reliability and validity results. Finally, the current study used a cross-sectional survey to examine customers' adoption of $\mathrm{m}$-banking in two countries, but number of respondents is not equal among two countries, it can make comparison between two countries difficult. Thus, future research is needed to replicate and validate the findings using a longitudinal research which would allow for further examination of m-banking adoption at multiple points of time.

\section{References}

Aboelmaged, M. G., \& Gebba, T. R. (2013). Mobile Banking Adoption: an Examination of Technology Acceptance Model and Theory of Planned Behavior. International Journal of Business Research and Development, 2(1), 35-50.

Akturan, U., \& Tezcan, N. (2012). Mobile banking adoption of the youth market: Perceptions and intentions. Marketing Intelligence \& Planning, 30(4),444-459.

Al-Gahtani, S. S. (2011). Modeling the electronic transactions acceptance using an extended technology acceptance model. Applied Computing and Informatics, 9(1), 47-77.

Al-Jabri, brahim M., \& Sohail, M. S. (2012). Mobile banking adoption: Application of diffusion of innovation theory. Journal of Electronic Commerce Research, 13(4), 379-391.
Aldás-Manzano, J., Lassala-Navarré, C., Ruiz-Mafé, C., \& SanzBlas, S. (2009). Key drivers of internet banking services use. Online Information Review, 33(4), 672-695. https://doi. org/10.1108/14684520910985675

Bhattacharya, C. B., \& Sen, S. (2004). Doing better at doing good: when, why, and how consumers respond to corporate social initiatives. California Management Review, 47(1), 9-24.

Brown, T. J., \& Dacin, P. A. (1997). The company and the Product: Company Associations and Corporate Consumer Product Responses. Journal of Marketing, 61(1), 68-84.

Carroll, A. B. (1979). A three-dimensional conceptual model of corporate performance. Academy of management review, 4(4), 497-505.

Carroll, A. B. (1998). The Four Faces of Corporate Citizenship. Business and Society Review, 100-101(1), 1-7. https://doi. org/10.1111/0045-3609.00008

Carroll, A. B. (2000). Ethical Challenges for Business in the New Millennium: Corporate Social Responsibility and Models of Management Morality. Business Ethics Quarterly, 10(1), 3342. https://doi.org/10.2307/3857692

Chan, T. S. (1996). Concerns for environmental issues and consumer purchase preferences: A two-country study. Journal of International Consumer Marketing, 9(1), 43-55.

Chin, W. W., Marcolin, B. L., \& Newsted, P. R. (2003). A Partial Least Squares Latent Variable Modeling Approach for Measuring Interaction Effects: Results from a Monte Carlo Simulation Study and an Electronic-Mail Emotion/Adoption Study. Information Systems Research, 14(2),189-217. https:// doi.org/10.1287/isre.14.2.189.16018

Cheng, T., Lama, D., \& Yeung, A. (2006). Adoption of internet banking: An empirical study in Hong Kong. Decision Support Systems, 42(3), 1558-1572.

Choi, B., \& La, S. (2013). The impact of corporate social responsibility (CSR) and customer trust on the restoration of loyalty after service failure and recovery. Journal of Services Marketing, 27(3), 223-233.

Coleman, R. (1990). Foundations of Social Theory. Belknap Press, Cambridge, MA, USA

Cruz, P., Neto, L. B. F., Muñoz-Gallego, P., \& Laukkanen, T. (2010). Mobile banking rollout in emerging markets: evidence from Brazil. The International Journal of Bank Marketing, 28(5), 342-371.

Dahlsrud, A. (2008). How Corporate Social Responsibility is defined: an Analysis of 37 definitions. Corporate Social Responsibility and Environmental Management, 13, 1-13.

Davis, F. D. (1986). A technology acceptance model for empirically testing new end-user information systems: theory and results. Ph.D. thesis. Massachusetts Institute of Technology, Cambridge, Massachusetts.

Davis, F. D. (1989). Perceived Usefulness, Perceived Ease of Use, and User Acceptance of Information Technology. MIS Quarterly, 13(3), 319-340. 
Davis, F. D., Bagozzi, R. P., \& Warshaw, P. R. (1989). User Acceptance Of Computer Technology: A comparison of two theoretical Models. Management Science, 35(8), 982-1003.

Davis, K. (1975). Five propositions for social responsibility. Business Horizons, 18(June), 19-24.

DeCarlo, L. T. (1997). On the meaning and use of kurtosis. Psychological Methods, 2(3), 292-307. https://doi. org/10.1037/1082-989X.2.3.292

Drumwright, M. E. (1996). Company Advertising with a Social Dimension: The Role of Noneconomic Criteria. The Journal of Marketing, 60(4), 71-87.

Faqih, K. M. S., \& Jaradat, M. I. R. M. (2015). Assessing the moderating effect of gender differences and individualismcollectivism at individual-level on the adoption of mobile commerce technology: TAM3 perspective. Journal of Retailing and Consumer Services, 22, 37-52.

Featherman, M. S., \& Pavlou, P. A. (2003). Predicting e-services adoption: A perceived risk facets perspective. International Journal of Human-Computer Studies, 59(4), 451-474. https:// doi.org/10.1016/S1071-5819(03)00111-3

Fornell, C., \& Larcker, D. F. (1981). Evaluating Structural Equation Models with Unobservable Variables and Measurement Error. Journal of Marketing Research, 18(1), 39-50.

Gefen, D., Karahanna, E., \& Straub, D. (2003). Trust and TAM in Online Shopping: An Integrated Model. MIS Quarterly, 27(1), 51-90. https://doi.org/10.2307/30036519

Grabner-Krauter, S., \& Kaluscha, E. A. (2003). Empirical research in on-line trust: A review and critical assessment. International Journal of Human-Computer Studies, 58(6), 783-812.

Gu, J. C., Lee, S. C., \& Suh, Y. H. (2009). Determinants of behavioral intention to mobile banking. Expert Systems with Applications, 36(9), 11605-11616.

Ha, K. H., Canedoli, A., Baur, A. W., \& Bick, M. (2012). Mobile banking - insights on its increasing relevance and most common drivers of adoption. Electronic Markets, 22(4), 217-227. https://doi.org/10.1007/s12525-012-0107-1

Han, S. L., Thao Nguyen, T. P., \& Nguyen, V. A. (2016). Antecedents of intention and usage toward customers' mobile commerce: Evidence in Vietnam. Journal of Global ScholarS of MarketinG Science, 26(2), 129-151. https://doi.org/10.1080 /21639159.2015.1116796.

Hanafizadeh, P., Behboudi, M., Abedini, K. A., \& Jalilvand, S. T. M. (2014). Mobile-banking adoption by Iranian bank clients. Telematics and Informatics, 31(1), 62-78.

Handelman, J. M., \& Arnold, S. J. (1999). The Role of Marketing Actions with a Social Dimension: Appeals to the Institutional Environment. Journal of Marketing, 63(3), 33-48.

Hatcher, L. (1994). A step-by-step approach to using the SAS system for factor analysis and structural equation modeling. Cary, NC: SAS Institute.

Hofstede, G. H. (1994). Cultures and organizations: Software of the mind: intercultural cooperation and its importance for survival. London, UK: Harper Collins.
Homburg, C., Koschate, N., \& Hoyer, W. D. (2005). Do Satisfied Customers Really Pay More? A Study of the Relationship Between Customer Satisfaction and Willingness to Pay. Journal of Marketing, 69(2), 84-96.

Hopkins, K. D., \& Weeks, D. L. (1990). Tests for Normality and Measures of Skewness and Kurtosis: Their Place in Research Reporting. Educational and Psychological Measurement, 50(4), 717-729. https://doi.org/10.1177/0013164490504001

Horton, R. P., Buck, T., Waterson, P. E., \& Clegg, C. W. (2001). Explaining Intranet use with the Technology Acceptance Model. Journal of Information Technology, 16(4), 237-249. https://doi.org/10.1080/02683960110102407

Jaruwachirathanakul, B., \& Fink, D. (2005). Internet banking adoption strategies for a developing country: the case of Thailand. Internet Research, 15, 295-311.

Jarvenpaa, S. L., Tractinsky, N., \& Vitale, M. (2000). Consumer trust in an Internet store. Information Technology and Management, 1(1), 45-71. https://doi.org/10.1023/A:1019104520776

Jeyaraj, A., Rottman, J. W., \& Lacity, M. C. (2006). A Review of the Predictors, Linkages, and Biases in IT Innovation Adoption Research. Journal of Information Technology, 21(1), 1-23. https://doi.org/10.1057/palgrave.jit.2000056

Kim, Y., \& Choi, S. R. (2005). Antecedents of green purchase behaviour: an examination of collectivism, environmental concern and PCE. Advances in Consumer Research, 32(1), 592-599.

Kim, H. W., Chan, H. C., \& Gupta, S. (2007). Value-based Adoption of Mobile Internet: An empirical investigation. Decision Support Systems, 43(1), 111-126. http://doi.org/10.1016/j. dss.2005.05.009

Kim, G., Shin, B., \& Lee, H. G. (2009). Understanding dynamics between initial trust and usage intentions of mobile banking. Information Systems Journal, 19(3), 283-311.

Koenig Lewis, N., Palmer, A., \& Moll, A. (2010). Predicting young consumers' take up of mobile banking services. Marketing Intelligence and Planning, 28(5), 410-432.

Laforet, S., \& Li, X. (2005). Consumers' attitudes towards online and mobile banking in China. International Journal of Bank Marketing, 23(5), 362-380.

Le, H. B. H., Ngo, C. T., Trinh, T. T. H., \& Nguyen, T. T. P. (2020). Factor Affecting Customers' Decision to Use Mobile Banking Service: A Case of Thanh Hoa Province, Vietnam. Journal of Asian Finance, Economics and Business, 7(2), 205-212. https://doi.org/10.13106/jafeb.2020.vol7.no2.205

Lederer, A. L., Maupin, D. J., Sena, M. P., \& Zhuang, Y. L. (2000). The technology acceptance model and the World Wide Web. Decision Support System, 29, 269-282.

Lee, K. C., \& Chung, N. (2009). Understanding factors affecting trust in and satisfaction with mobile banking in Korea: A modified DeLone and McLean's model perspective. Interacting with Computers, 21(5-6), 385-392.

Leigh, J. H., Murphy, P. E., \& Enis, B. M. (1988). A new approach to measuring socially responsible consumption 
tendencies. Journal of Macromarketing, 8(1), 5-20. https://doi. org/10.1177/027614678800800102

Liao, C., Liu, C. C., \& Chen, K. (2011). Examining the impact of privacy, trust and risk perceptions beyond monetary transactions: An integrated model. Electronic Commerce Research and Applications, 10(6), 702-715.

Luarn, P., \& Lin, H. H. (2005). Toward an understanding of the behavioral intention to use mobile banking. Computers in Human Behavior, 21(6), 873-891.

Luo, X., \& Bhattacharya, C. B. (2006). Corporate Social Responsibility, Customer Satisfaction, and Market Value. Journal of Marketing, 70(4), 1-18.

Luo, X., Li, H., Zhang, J., \& Shim, J. P. (2010). Examining multidimensional trust and multi-faceted risk in initial acceptance of emerging technologies: An empirical study of mobile banking services. Decision Support Systems, 49(2), 222-234.

McKnight, D. H., Cummings, L. L. \& Chervany, N. L. (1998). Initial trust formation in new organization relationships. Academy of Management Review, 23, 473-490.

Maignan, I., \& Ferrell, O. C. (2000). Measuring Corporate Citizenship in Two Countries: The Case of the United States and France. Journal of Business Ethics, 23(3), 283-297.

Málovics, G., Csigéné, N. N., \& Kraus, S. (2008). The role of corporate social responsibility in strong sustainability. The Journal of Socio-Economics, 37(3), 907-918. https://doi. org/10.1016/j.socec.2006.12.061

Mohammadi, H. (2015). A study of mobile banking loyalty in Iran. Computers in Human Behavior, 44, 35-47.

Nasri, W., \& Charfeddine, L. (2012). Factors affecting the adoption of Internet banking in Tunisia: An integration theory of acceptance model and theory of planned behavior. The Journal of High Technology Management Research, 23(1), 1-14. https://doi.org/10.1016/j.hitech.2012.03.001

Olson, J. R., \& Boyer, K. K. (2003). Factors influencing the utilization of Internet purchasing in small organizations. Journal of Operations Management, 21(2), 225-245. https:// doi.org/10.1016/S0272-6963(02)00089-X

Park, J. C., \& Lee, K. H. (2009). The effects of corporate efforts for the sustainable management on the corporate trust and customer satisfaction. Asia-Pacific Journal of Business \& Commerce, 12, 1-22.

Pavlou, P. A. (2003). Consumer Acceptance of Electronic Commerce: Integrating Trust and Risk with the Technology Acceptance Model. International Journal of Electronic Commerce, 7(3), 69-103.

Phuong, N. N. D., Luan, L. T., Dong, V. Van, \& Khanh, N. L. N. (2020). Examining Customers' Continuance Intentions towards E-wallet Usage: The Emergence of Mobile Payment Acceptance in Vietnam. Journal of Asian Finance, Economics and Business, 7(9), 505-516. https://doi.org/10.13106/ jafeb.2020.vol7.no9.505

Tahar, A., Riyadh, H. A., Sofyani, H., \& Purnomo, W. E. (2020). Perceived Ease of Use, Perceived Usefulness, Perceived
Security and Intention to Use E-Filing: The Role of Technology Readiness. Journal of Asian Finance, Economics and Business, 7(9), 537-547. https://doi.org/10.13106/jafeb.2020.vol7. no9.537

Turban, E., King, D., Viehland D., \& Lee, J. (2006). Electronic commerce 2006: A managerial perspective. Upper Saddle River, NJ: Pearson Education.

Del Mar Garcia de los Salmones, M., Perez, A., \& Rodriguez del Bosque, I. (2009). The social role of financial companies as a determinant of consumer behaviour. International Journal of Bank Marketing, 27(6), 467-485. https://doi. org/10.1108/02652320910988339

Sen, S., \& Bhattacharya, C. B. (2001). Does Doing Good Always Lead to Doing Better? Consumer Reactions to Corporate Social Responsibility. Journal of Marketing Research, 38(2), 225-243.

Sims, R. L., \& Gegez, E. (2004). Attitudes towards Business Ethics: A Five Nation Comparative Study. Journal of Business Ethics, 50(3), 253-265. https://doi.org/10.1023/ B:BUSI.0000024708.07201.2d

Sirdeshmukh, D., Singh, J., \& Sabol, B. (2002). Consumer Trust, Value, and Loyalty in Relational Exchanges. Journal of Marketing, 66(1), 15-37.

Suh, B., \& Han, I. (2002). Effect of trust on customer acceptance of Internet banking. Electronic Commerce Research and Applications, 1(3-4), 247-263. https://doi.org/10.1016/S15674223(02)00017-0

Swaen, V., \& Chumpitaz, R. C. (2008). Impact of Corporate Social Responsibility on Consumer Trust. Recherche et Applications En Marketing, 23, 7-34.

Van der Heijden, H. (2004). User Acceptance of Hedonic Information Systems. MIS Quarterly, 28(4), 695-704. https:// doi.org/10.2307/25148660

Venkatesh, V., \& Davis, F. D. (2000). A Theoretical Extension of the Technology Acceptance Model: Four Longitudinal Field Studies. Management Science, 46(2), 186-204. https://doi. org/10.1287/mnsc.46.2.186.11926.

Venkatesh, V., Morris, M. G., Davis, G. B., \& Davis, F. D. (2003). User acceptance of information technology: Toward a unified view. MIS Quarterly, 27(3), 425-478.

Verhoef, P. C. (2005). Explaining purchases of organic meat by Dutch consumers. European Review of Agricultural Economics, 32(2), 245-267. https://doi.org/10.1093/eurrag/ jbi008

Vlachos, P. A., Tsamakos, A., Vrechopoulos, A. P., \& Avramidis, P. K. (2009). Corporate social responsibility: attributions, loyalty, and the mediating role of trust. Journal of the Academy of Marketing Science, 37(2), 170-180.

Wang, Y. S., Lin, H. H., \& Luarn, P. (2006). Predicting consumer intention to use mobile service. Information Systems Journal, $16,157-179$.

Wang, Y., Lo, H. P., \& Hui, Y. V. (2003). The antecedents of service quality and product quality and their influences on 
bank reputation: evidence from the banking industry in China. Managing Service Quality, 13(1), 72-83.

Wei, T. T., Marthandan, G., Chong, A. Y. L., Ooi, K. B., \& Arumugam, S. (2009). What drives Malaysian m-commerce adoption? An empirical analysis. Industrial Management \& Data Systems, 109(3), 370-388.

Wessels, L., \& Drennan, J. (2010). An investigation of consumer acceptance of M-banking. International Journal of Bank Marketing, 28(7), 547-568.

Wu, I. L., \& Chen, J. L. (2005). An extension of Trust and TAM model with TPB in the initial adoption of online tax: An empirical study. International Journal of Human-Computer Studies, 62(6), 784-808. https://doi.org/10.1016/j.ijhcs.2005.03.003

Yiu, C. S., Grant, K., \& Edgar, D. (2007). Factors affecting the adoption of Internet Banking in HongKong implications for the banking sector. International Journal of Information Management, 27(5), 336-351.
Zenisek, T. J. (1979). Corporate Social Responsibility: A Conceptualization Based on Organizational Literature. The Academy of Management Review, 4(3), 359-368.

Zhou, T. (2011). The effect of initial trust on user adoption of mobile payment. Information Development, 27(4), 290-300.

Zhou, T. (2012). Understanding users' initial trust in mobile banking: an elaboration likelihood perspective. Computers in Human Behavior, 28(4), 1518-1525. https://doi.org/10.1016/j. chb.2012.03.021.

Zhou, T., Lu, Y., \& Wang, B. (2010). Integrating TTF and UTAUT to explain mobile banking user adoption. Computers in Human Behavior, 26(4), 760-767.

Zhu, Q., Sarkis, J., \& Lai, K. H. (2013). Institutional-based antecedents and performance outcomes of internal and external green supply chain management practices. Journal of Purchasing and Supply Management, 19(2), 106-117. 